\title{
The Effect of Mechanical Massage on Lower Extremities as Passive Recovery to the Leg Muscle Strength After Plyometrics Training
}

\author{
Atradina $^{1 *}$, R Sepriani $^{1}$ \\ ${ }^{I}$ Fakultas Ilmu Keolahragaan Universitas Negeri Padang \\ *Corresponding author. Email: atr_pykh@yahoo.co.id
}

\begin{abstract}
The aim of the studyis to observe the influence ofmechanical massage on lower extremities muscles to speed up the recovery after physical training. A quasi-experimental design was conducted by giving treatment to the samples of 20 football athletes of UNP using purposive sampling technique. Selected samples have to do the plyometrics training, and testing of the legmuscle strenght was conducted (pre-test). After the exercise, the samples were given passive recovery treatment in the form of local massage on the lower leg muscles and the leg muscle strength test was taken using leg dynamometer.The data analyzed by using t-test. Based on data analysis leg muscle strength before doing plyometrics training was $151.2 \mathrm{~kg}$, and after exercise plyometrics (post-test) was $124.15 \mathrm{~kg}$. After given a treatment in the form of massage lower extremities and leg muscle strength measured again(posttest) the average of leg muscle strength was $127.65 \mathrm{~kg}$. From the data analysis it can be concluded that: there are significant differences between pretest and posttest massage of the lower extremities as a passive recovery of the leg muscle strength after plyometrics workout at significance level $\alpha$ $=0.05$.
\end{abstract}

Keywords: Mechanical massage, lower extremities, passive recovery, leg muscle strength, plyometrics training

\section{INTRODUCTION}

The founding of achievement sport requires athletes' performances that are always excellent and improved. Simply, it requires long-term and progressive physical enhancement and technical exercises integratedly. Both, especially physical exercise will cause fatigue. Fatigue as it is known will affect the athlete performance as well as his technique. An athlete is undergoing rigorous training beyond the limits of their physiological and psychological abilities. In addition, athletes get the pressure both professionally and environmentally, which causes compressive leading to stress.

Exercise is a conscious effort that is done in a sustainable and systematic way to improve the functional ability of the body (Giriwijoyo, 2010). Exercise is one of the modulator of biological functions that are double, which can cause positive effects (improving and repairing), as well as negative effects (reducing and damaging). A well-done, regular, prolonged, and appropriate exercise will lead to an increase in the body's adaptation system (Harjanto, 2004). The negative effects of exercise as proposed by Byrne et al. (2004) is an exercise that can damage muscle fibers indicated by abnormalities of muscle function, stiffness and swelling of the muscles. Burnley et al. (2010) also states that the symptoms of muscle damage that generally occur due to exercise include: pain (soreness), decreasing muscle strength, range of motion (ROM), increasing inflammatory response and increasing creatine phosphokinase serum levels in blood.

The cause of this condition is the body muscles which are too tired, causing pain or stiffness (fatique). In heavy activities, it often occurs that muscle fibers are broken or torn so that it will be even more painful. The type of exercises that affect the symptoms of muscle damage and requires the longest recovery time is the exercise that uses high-force eccentric muscle actions such as resistance training, plyometrics, drop jump and downhill running (Street et al., 2011). Plyometrics is an exercise method that can increase the muscle's natural ability to contract stronger and faster. By reducing time and increasing muscle strength from eccentric contractions into concentric contractions of muscle action known as shortened spins, athletes can increase their ability to accelerate the production of higher forces. Strength is the ability of muscles or muscle groups to do the work, by holding the load lifted. 
The recovery process after doing exercise is very important and it is recommended to reduce fatigue and body imbalance due to exercise. The process of restoring the physical condition is often done with passive recovery. Passive recovery is a recovery process in the absence of physical activity, ie silence, total rest (sitting, supine, sleeping sauna, acupuncture, massage etc.) The effect of passive recovery, on muscle (muscle fatigue) in order to recover like before as well as to repair minor muscle damage (microtear). From all stated above, massage is the most common and most popular thing.

Massage is the act by hand (manipulation) on the soft parts of the body with manual or mechanical procedures that have an effect in removing burning residues in muscles, such as lactic acid. Because massage can smooth blood circulation in the muscles, it can enlarge the oxygen transport and accelerate the course of metabolism in the body. The effect of massage on the body has a mechanical effect. Mechanical effect is the direct influence of massage work that stimulates the skin and tissues. Massage stimulation has a warming effect on the body as well as pressure on blood vessels and lymphe that causes the blood is flowed and lymphe is pushed into the heart. (Darni, 2009). Massage has several types according to function, ie massage as a warming up (done before the start of activity), massage as a sedative and stabilizing the appearance (done during the activity) and massage as recovery (done after the activity).

Principally, massage after exercise is to speed up the return of homeostasis function, overcoming muscle tension, cramps and inflammation (Callaghan 1993). Muscle strength is a very important component to improve overall physical condition. Therefore, an absolute power must be possessed by an athlete before he or she practices other elements. Strength is the basis of all components of physical conditions, especially in football. Leg muscle strength is needed by soccer athletes in a kick to the goal and score goals. The role of leg muscle strength is crucial, because it is the leg muscle strength that serves to swing the legs kicking toward the front to be done quickly and in a relatively short time.

\section{METHOD}

This research used quasi experimental design. This study aimed at determining the number of changes generated by the treatment. The schedule of this research was on August-September 2017 and implemented in FIK UNP football field. Population is the whole subject to be investigated (Arikunto, 2002). Population in this research was FIK UNP football athlete. The sample is simply defined as a population that will serve as a source of data in a study (Arikunto, 2010). Arikunto (2010) suggests that if a population is less than 100, it is better taken entirely. Conversely, if it is more than 100, then the sample is taken about 10 $25 \%$.

The sample in this study was taken by using purposive sampling technique, that is taken with a particular purpose that meet the inclusion criteria; that is willing to be a respondent, healthy and not doing eccentric exercise at least for 2 days. The tools used in this research were massage equipments. The tools used in this research were leg dynamometer used to measure leg muscle strength, bench as high as $50 \mathrm{~cm}$, stationery, and stopwatch.

The procedures of this study are as follows:

1. Preparation phase:

Preparing research instruments

Providing guidance to sample about research implementation

2. Implementation Phase:

The sample was measured their leg muscle strength before performing pliometric exercises.

The sample did warming up before starting the pliometric exercise.

Each sample was prepared himself by occupying their positions

Samples performed pliometric exercises as many as 10 sets (10 reps per set) within recovery time is 1 minute per set

After completing pliometric exercises, the leg muscle strength was measured (pre test)

1 hour after exercise, the sample was given treatment in the form of local massage of leg muscle (lower limb).

After being given passive recovery treatment in the form of local massage of lower limb, the sample was tested his leg muscle strength with leg dynamometer (posttest)

\section{RESULTS}

Leg Muscle Strength Before Activity (Preactivity)

Based on research data, it was obtained that the lowest leg muscle strength was $136 \mathrm{~kg}$ and the highest $195 \mathrm{~kg}$. From the data analysis, the average strength of leg muscle was 151,20 , standard deviation was 23,41 , Median was 148 . The frequency distribution is shown in the following table 1:

Table 1. Frequency Distribution of Leg Muscle Strength (Preactivity)

\begin{tabular}{lccl}
\hline $\begin{array}{l}\text { Interval } \\
\text { Class }\end{array}$ & $\begin{array}{l}\text { Absolute } \\
\text { Frequency }\end{array}$ & $\begin{array}{l}\text { Relative } \\
\text { Frequency }(\%)\end{array}$ & $\begin{array}{l}\text { Classific } \\
\text { ation }\end{array}$ \\
\hline$<137$ & 6 & 30 & $\begin{array}{l}\text { Very } \\
\text { Poor }\end{array}$ \\
$137-159$ & 7 & 35 & Poor \\
$160-213$ & 7 & 35 & Fair \\
$214-240$ & 0 & 0 & Good \\
$>241$ & 0 & 0 & Very \\
\hline
\end{tabular}


Good

Total

20

100

From the table above, it can be seen from 20 respondents that the most abundant one was in the interval class 137-159 and 160-213 as many as 7 people for each class $(35 \%)$, which are in the poor and fair classification, the next is in interval class $<137$ as much as 6 people $(30 \%)$ which is in very poor classification, and no one is in the interval class 214-240 and > 241, which are in good and very good classification. For more details can be seen in the following histogram:

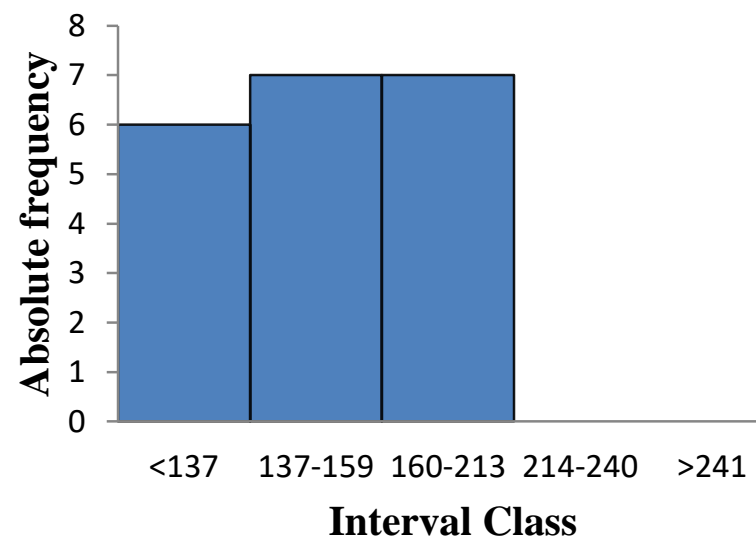

Figure 1. Histogram of Leg Muscle Strength Preactivity

\section{Leg Muscle Strength Before Treatment (Pretest)}

Based on research data, it was obtained that the lowest leg muscle strength was $89 \mathrm{~kg}$ and the highest was $168 \mathrm{~kg}$. From the data analysis, it was found that the average limb muscle strength value was 124,15 , standard deviation was 21,60, Median was 123 . The frequency distribution is shown in the following table:

Table 2. Frequency Distribution of Leg Muscle Strength (Pretest)

\begin{tabular}{|c|c|c|c|}
\hline Interval & Absolute & Relative & Classific \\
\hline Class & Frequency & Frequency $(\%)$ & ation \\
\hline$<137$ & 14 & 70 & $\begin{array}{l}\text { Very } \\
\text { Poor }\end{array}$ \\
\hline $137-159$ & 4 & 20 & Poor \\
\hline $160-213$ & 2 & 10 & Fair \\
\hline $214-240$ & 0 & 0 & Good \\
\hline$>241$ & 0 & 0 & $\begin{array}{l}\text { Very } \\
\text { Good }\end{array}$ \\
\hline Total & 20 & 100 & \\
\hline
\end{tabular}

From the table above, it can be seen from 20 samples that the leg muscle strength are mostly found in interval class of $<137$ as many as 14 people (70\%) which is in very poor classification, then there are 4 people $(20 \%)$ in the interval class $137-159$ which is in poor classification, 2 (10\%) people are in 160-213 interval class which is in fair classification and no one in the 214-240 and > 241 interval class which is in good and very good classification. For more details, it can be seen in the following histogram:

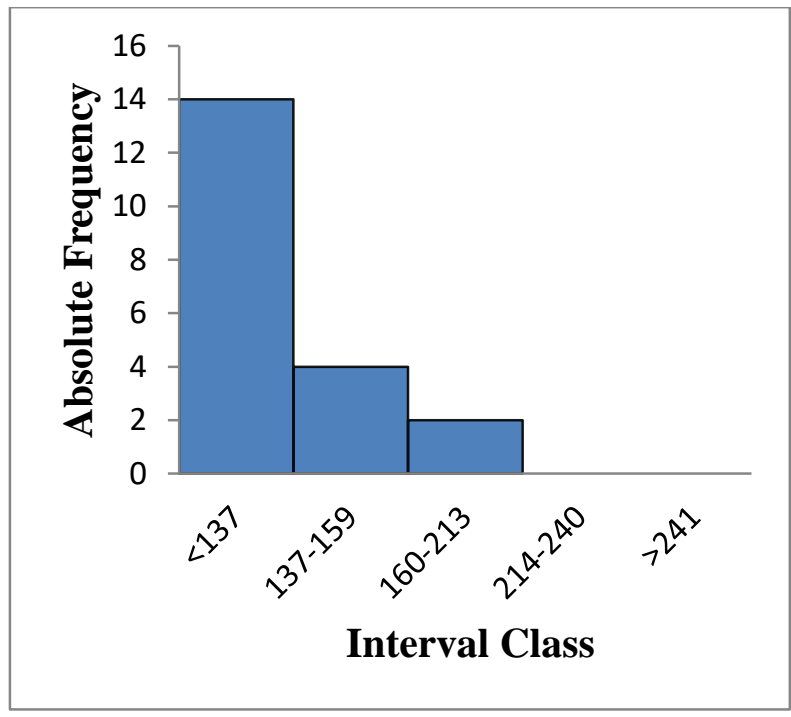

Figure 2. Histogram of Leg Muscle Strength (Pretest)

\section{Leg Muscle Strength After Treatment (Posttest)}

Based on the research data, it was obtained that the lowest leg muscle strength was $100 \mathrm{~kg}$ and the highest was $170 \mathrm{~kg}$. From the data analysis, the average strength of leg muscle was 127.65 , standard deviation was 20.65 , Median was120. The frequency distribution is shown in the following table:

Table 3. Frequency Distribution of Leg Muscle Strenght (Posttest)

\begin{tabular}{lccl}
\hline $\begin{array}{l}\text { Interval } \\
\text { Class }\end{array}$ & $\begin{array}{c}\text { Absolute } \\
\text { Frequency } \\
137\end{array}$ & $\begin{array}{c}\text { Relative } \\
\text { Frequency }(\%)\end{array}$ & $\begin{array}{l}\text { Classific } \\
\text { ation } \\
\text { Very } \\
\text { Poor }\end{array}$ \\
$137-159$ & 7 & 60 & Poor \\
$160-213$ & 1 & 35 & Fair \\
$214-240$ & 0 & 5 & Good \\
$>241$ & 0 & 0 & Very \\
Total & 20 & 0 & Good \\
\hline
\end{tabular}

From the table above, it can be seen from 20 samples that the mostly leg muscle strength is in the interval class of $<137$ as many as 12 people $(60 \%)$ which is in the classification of very poor, while there are 7 people $(35 \%)$ in the interval class of 137-159 which is in poor classification, 1 person $(5 \%)$ are in 160-213 interval class which is in fair classification and no single person is in the interval class 214-240 and> 241 which is in good and very good classification. For more details, it can be seen in the following histogram: 


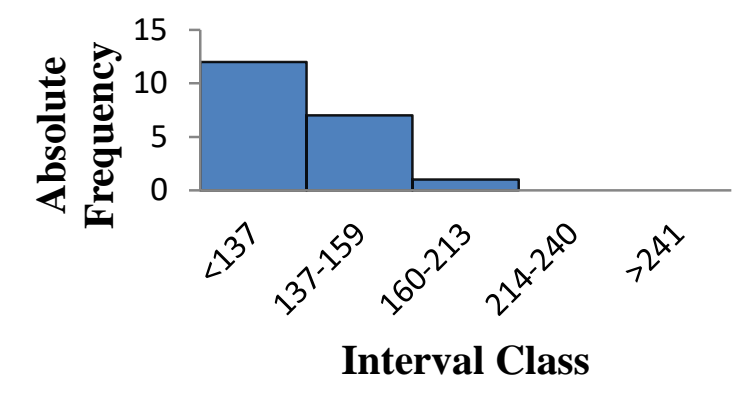

Figure 3. Histogram of Leg Muscle Strength (posttest)

The average value of leg muscle strength (Pretest and Posttest)

In this study, the measurement of leg muscle strength to research subjects was done before and after giving the treatment by using a legdynamometer. The mean measurements of leg muscle strength before giving the treatment was 124.15 and after the treatment was 127.65. For more details, it can be seen in the table below:

Table 4. The mean value of leg muscle strength

\begin{tabular}{|c|c|c|c|c|}
\hline \multirow[t]{2}{*}{ No. } & \multirow{2}{*}{\multicolumn{2}{|c|}{ Variable }} & \multicolumn{2}{|c|}{ Maximum average of $\mathrm{VO} 2$} \\
\hline & & & Pretest & Posttest \\
\hline 1. & $\begin{array}{l}\text { Leg } \\
\text { Strenght }\end{array}$ & Muscle & 124,15 & 127,65 \\
\hline
\end{tabular}

For more details of leg muscle strength average value before and after giving the treatment, it can be seen in the histogram below:

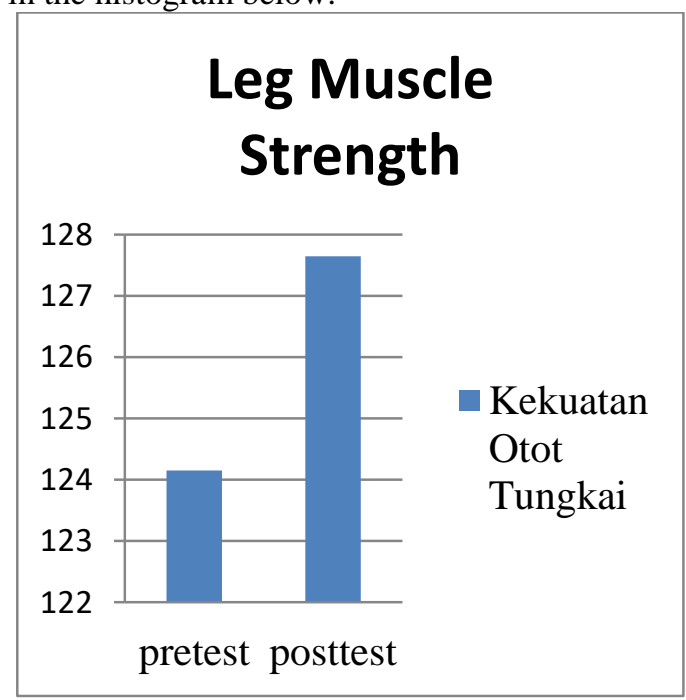

Figure 4. Histogram of The average value of leg muscle strength
Leg muscle strength is the ability of the muscles to accept the load, where the ability is produced by the contraction of muscles in the limbs/leg, in which this contraction arises to perform a supportive movement. Andi Suhendro (2004) said that one element of physical condition that needs to be trained first is the element of the physical condition of strength/power, because strength has an important role in protecting athletes from injury and in helping to stabilize the joints. Strength means the ability to exert maximum power in one effort/try, the power ability means the occurrence of muscle contraction in humans, where there are three types of contractions, namely; static, concentric and eccentric.

Pliometric exercise is an exercise to help the muscles reach the peak of strength in a relatively short period of time. Pliometrics is an exercise method that can increase the muscle's natural ability to contract stronger and faster. By reducing time and increasing muscle strength from eccentric contractions into concentric contractions of muscle action known as shortened spins, athletes can increase their ability to accelerate the production of higher forces. According Ebben (2007), he mentions pliometric exercise is an exercise that can increase fast muscle fibers and nerves that supply the muscle fibers, called stretch reflex, and the purpose of pliometric exercise is to emphasize the power as a combination of speed and strength.

When the body does physical exercise which is a form of physical stressor, it can cause homeostatic disorders, and the body will respond (effect) in the form of a negative feedback mechanism (Bawono, 2008). The response is a response (acute effect) and adaptation (chronic effects). The pliometric exercise is a purely anaerobic exercise that uses the keratin phosphate energy system (Chu, 2010). When we are doing a strenuous physical exercise program, things to keep in mind other than continuing to boost physical exercise is a recovery phase for athletes.

In this research, the data of leg muscle strength is collected three times before doing pliometric exercise, after doing pliometric (pretest) and after massage (posttest) exercise. Before doing pliometric exercise, the average of leg muscle strength is $151,2 \mathrm{~kg}$. After doing plyometric exercise (pretest), the average of leg muscle strength is $124,15 \mathrm{~kg}$ which is a decrease about $27,05 \mathrm{~kg}(17,9 \%)$ than before practicing. Then, the samples were given the treatment of lower limb extremity massage. After that, the leg muscle strength was re-measured (posttest) and it was obtained that the average value of leg muscle strength was $127.65 \mathrm{~kg}$, which is increased after treating pliometric exercise as much as $3.5 \mathrm{~kg}(2.8 \%)$.

Before conducting the data analysis, the normality was tested by using Liliefors. Based on the normality test, it was obtained that the value of $\mathrm{L}_{0}$ and $\mathrm{L}_{t}$ at 0.05 
level for $\mathrm{n}=20$. Testing Criteria showed that $\mathrm{L}_{0}<\mathrm{L}_{\mathrm{t}}$ then the sample was normally distributed. Then, the data was analyzed by doing $t$ test. From the analysis of data, it was obtained that $t_{\text {observed }}(53,63078)<t_{\text {tabel }}$ $(1,729)$ at significance level $\alpha=0,05$. So, it can be seen that $\mathrm{Ha}$ is accepted and Ho is rejected. Thus, there is a significant difference between pretest and posttest of local massage mechanism to the lower limb extremities as a passive recovery of leg muscle strength after pliometric exercise.

The negative effects of exercise as proposed by Byrne et al. (2004) is an exercise that can damage muscle fibers that are indicated by abnormalities of muscle function, stiffness and swelling of the muscles. Burnley et al. (2010) also states that the symptoms of muscle damage that generally occur due to exercise include pain (soreness), decreased muscle strength, range

motion (ROM), increasing inflammatory response, increasing creatine phosphokinase serum levels in blood. According Joesoef (2015), the cause is the muscles of the body is too tired, causing pain or aches (fatique). In very heavy activities, it is often occurred that muscle fibers are broken or torn so that the pain will be even more painful.

According to Jackman (2011), after a contraction involving muscle elongation, it causes a damage to the sarcoma that may cause excitation-contraction coupling is impaired, resulting in a decrease in muscle strength. Eccentric contractions result in greater extent of myofibril damage due to excessive strain of the sarcoma resulting in disruption of sarcolemma and reshuffle of contractile machinery, leading eventually to a decrease in muscle strength due to impaired exitatoncontraction couplin (Willoughby 2003). But after one hour of local massage treatment given in lower extremities, it increased the percentage of leg muscle strength

Massage is the most common and most popular thing done in the process of restoring the physical condition after exercise. Massage can smooth blood circulation in the muscles, can enlarge the transport of oxygen and accelerate the course of metabolism in the body. According to Nancy \& Robertson in Joesoef (2015), the use of special massage techniques as an idea to produce local enhancement in the skeletal muscle circulation can be done in several ways, which directly affects the tissues, changes in circulation for local release of the vasodilator and decreases the reflexes in the sympathetic nerves caused by stimulating the network directly. Theoretically, an increase in blood flow to the skeletal muscle as a path of lactate flow rate acceleration can speed up the clearance. Manipulation of massage given to athletes is intended to diagnose the presence or absence of physical disorders before or after exercise, improve physical disturbance, mobilize and restore muscle tone, trigger relaxation, stimulate circulation to accelerate the recovery process.

\section{CONCLUSIONS}

From the research that has been done, it can be concluded as follows: The average value of leg muscle strength before pliometric exercise is $151.2 \mathrm{~kg}$. The average value of leg muscle strength after pliometric exercise (pretest) is $124,15 \mathrm{~kg}$. The average value of leg muscle strength after giving massage treatment (posttest) is $127.65 \mathrm{~kg}$

There is a statistically significant difference between pretest and posttest local massage of the lower lomb extremities as a passive recovery of leg muscle strength after pliometric exercise.

For the trainers, it should be considered about the balance between training and recovery portion so as to avoid injury. Besides, add recovery options with masage to help restore athletes' condition.

For the management of the team, it should be prepared masseur (masseur) who understand the anatomy and physiology of the human body, so as to help optimizing the performance of athletes. For other researchers, it calls for similar research using different recovery methods.

\section{REFERENCES}

[1] Andi Suhendro. 2004. Dasar-dasar Kepelatihan. Jakarta: Universitas Terbuka.

[2] Burnley DE, Angela NO, Sharp RL, Bailer SW, Alekel DL, 2010. Impact of Protein Suplements on Muscle Recovery After Exercise-Induced Muscle Soreness. Journal Exercise Science Fitness. 8: 89-96.

[3] Byrne C, Twist C, Eston R, 2004. Neuromuscular Function After Exercise Induced Muscle Damage: Theoritical and Applied Implications. Journal Sport Medicine. 34: 49-69.

[4] Callaghan, M. J. (1993). The Role Of Massage in The Management of The Athlete: a Review. British Medical Journal 27(1): 28.

[5] Chu. D. 2010. Jumping Into Plyometrics. 2nd ed. Champaign, Illinois: Human Kinetics.

[6] Darni. 2009. Masase Olahraga: Dasar Teori dan Manipulasi. Semarang: Wineka Media.

[7] Ebben, William, 2007. Practical Guidelines for Plyometric Intensity. Colorado: National Strength and Conditioning Association.

[8] Giriwijoyo, Sidik, 2010. Ilmu Faal Olahraga. Fungsi Tubuh Manusia pada Olahraga untuk Kesehatan dan Prestasi. Bandung: FPOK UPI.

[9] Harjanto. 2004. Latihan Olahraga. Jakarta : Erlangga. 
[10] Jackman SR. 2011. Whole Body and Muscle Response To Protein and Branched Chain Amino Acid Feeding Following Intense Exercise. $\quad$ Exercise Metabolism Research Group. Thesis. School of Sport and Exercise Sciences. University of Birmingham.

[11] Joesoef Roepajadi. 2015. Perbedaan Pengaruh Pemanasan dengan Metode Masase Lokal dan Peregangan Pasif Terhadap Kelincahan Otot Tungkai ( Ekstremitas Bawah ). Proceding Seminar dan Workshop Keolahragaan. Surabaya: FIK Unesa.

[12] Street B, Ch8rystoper B, Reger R, 2011 . Glutamine Supplementation in Recovery From Eccentric Exercise Attenuates Strength Loss and Muscle Damage. Journal exercise sience fitness. 9: 116-122.

[13] Willoughby DS, Clesivanenk, Lemuel Taylor. 2003. Effects of Concentric and Eccentric Contractions on Exercise- Induced Muscle Injury, Inflamation and Serum IL-6. Journal of The American Society of Exercise Physiologists. Vol 6. 